\title{
A Cultural Approach to a Canadian Tragedy: The Indian Residential Schools as a Sacred Enterprise
}

\author{
Eric Taylor Woods, 2013
}

\begin{abstract}
For over a century, the Canadian state funded a church-run system of residential schools designed to assimilate Aboriginal children into Euro-Canadian culture. In addition to the problems associated with its ethnocentric philosophy, the school system was also characterised by terrible health conditions and physical and sexual abuse of the students was widespread. Recently, the schools have been the object of the most successful struggle for redress in Canadian history. One particularly puzzling aspect about the school system is that it persisted for so long, despite that many of its failings were known very early in its operation. In this article, this puzzle is addressed via a cultural analysis of a political struggle over the residential schools that occurred within Canadian Anglicanism at the outset of the twentieth century. The article concludes that the meaning of the school system as a sacred enterprise contributed to its persistence.
\end{abstract}

Keywords: Indian residential schools; Canada; Anglican Church; Cultural analysis; Jeffrey Alexander; Victor Turner

Inspired by a similar practice in the USA, in the 1880s the Canadian government began to establish a system of industrial and residential schools whose intent was the assimilation of Aboriginal children into the working classes of Euro-Canadian culture. The schools were operated by several Christian churches that had long been involved in missionary work among Aboriginal people in North America (Miller 1996, pp. 39-61). The logic of the schools was as follows: by removing Aboriginal children from the influence of their parents and communities and placing them under the care of Christian educators, it was thought that the children would more quickly be assimilated (Miller 1996, pp. 61-121; Milloy 1999, pp. 1-23).

Initially, the focus was on expanding the industrial school system rather than the residential schools. Although the two types of schools shared the aim of assimilation, there were differences. In general, the industrial schools were aimed more at providing training for working class jobs, whereas the residential schools were focused on literacy and numeracy. Also, the industrial schools tended to be located further from the children's communities than the residential schools (on these differences, see Smith, 2001, pp. 256-59). However, in time, the aims of the two types of schools blurred and, after a reorganization of Aboriginal education in the 1920s, they collectively became known as residential schools. In this article, for simplicity, I shall also collectively refer to the two types of schools as residential schools even though the period under analysis precedes the reorganisation of the schools.

After its reorganisation in the 1920 s, the residential school system rapidly expanded, with a peak of 80 schools in 1931 (Milloy 1999, pp. 51-77). In the 1960s, amid the rising visibility of Aboriginal resistance to assimilation and an ideological sea change among non-Aboriginal Canadians, the residential schools began to be closed, converted into hostels for Aboriginal children attending nearby day schools or converted into halfway houses for children whose parents were deemed to be unfit for parenting (Milloy 1999, pp. 189-295). The last residential school closed in 1996. By some estimates, over 150,000 Aboriginal children spent some time in a residential school (Truth and Reconciliation Commission of Canada, online).

For many children, the experience of the residential schools was appalling. The residential schools were often poorly built and unsanitary. Many students suffered from malnourishment, inadequate clothing, insufficient medical care and death from disease was not uncommon (Milloy 1999, pp. 77-129). Additionally, it is now widely acknowledged that psychological, physical and sexual abuse was widespread throughout the schools. The Report of the Royal Commission on Aboriginal Peoples, created by the Canadian government in 1991 to investigate the situation of Aboriginal people in Canada, states, 'a reign of disciplinary terror, punctuated by incidents of stark abuse-continued to be the ordinary tenor of many schools' (Canada 1996, p. 356).

In recent decades, the residential schools have been the object of the most significant struggle for redress in Canadian history. In 2008, Prime Minister of Canada Stephen Harper publicly apologised on behalf of the Canadian government for the residential schools. This was followed by apologies from the leaders of all of Canada's major political parties. In conjunction with the apology, the Harper government offered financial compensation to former students. As of 12 September 2012, over 1.6 billion (CAD) had been paid (Aboriginal Affairs and Northern Development Canada, online). Harper also pledged to create a Residential Schools Truth and Reconciliation Commission (TRC). In 2010, the TRC began its work.

One particularly puzzling aspect of the unfortunate history of the residential schools is the finding by historian John Milloy (1999) that many of their failings were known to administrators from the turn of the twentieth century onwards. What is more, Milloy (1999) notes that, due to these failings, as well as the rapidly increasing costs of operating the residential schools, numerous administrators had early on sought to replace them with a system of day schools. Yet, the tragedy of the residential schools persisted. In this article, I seek to help explain this puzzle by 
uncovering the cultural elements involved in the persistence of the residential schools. To do so, I undertake a cultural analysis using an approach that combines Jeffrey Alexander's strong program with Victor Turner's social drama model.

Empirically, I focus on a struggle over the meaning of the residential schools that occurred at the outset of the twentieth century within the Anglican Church of Canada (formerly the Church of England in Canada). After the Roman Catholic Church, the Anglican Church was responsible for the second highest number of residential schools (Anglican Church of Canada, online). Canadian Anglicanism was involved in the residential school system from its creation in the 1880s until the Canadian government terminated the church-state partnership in Aboriginal education in 1969. In 1993, former Primate Michael Peers offered an apology for the Anglican church's role in the residential schools. Since the apology, Aboriginality and Anglicanism, at least among church elites, seem to have increasingly moved towards reconciliation. In 2001, Canada's first Aboriginal Anglican Bishop Gordon Beardy unexpectedly extended forgiveness to the church for its role in the residential schools (Larmondin 2001). In 2007, an office for a National Indigenous Anglican Bishop was created, which is considered a significant step towards Aboriginal Anglican self-determination (Anglican Church of Canada, online).

During the period to be analysed, the church's role in the residential schools was hotly debated among elites, with some calling for the withdrawal of the church. In analysing why the church did not withdraw from the residential school system, I hope to uncover why so many Anglicans were so supportive of it, despite rapidly increasing costs and the publication of numerous reports citing poor standards of education and sanitation. My rationale for focusing on a period of political struggle is informed by Victor Turner's (1974, p. 35) suggestion that it is during such periods that underlying meanings are most visible. My analysis is based on close reading of archival material gathered at the Anglican Church House Archives in Toronto, including a series of pamphlets, letters, editorials and minutes of meetings. Two previous studies on the topic of the debate over the residential schools that occurred within Canadian Anglicanism at the turn of the twentieth century also served as valuable sources of information and helped orient the research (see Lewis 1966; Porter 1981).

A broader aim of this study is to help spur a new research agenda on the residential schools. Research on the historical aspects of the school system has heretofore focused on filling empirical gaps (e.g.Miller 1996; Milloy 1999). Meanwhile, social scientists have been focused on the prospects for reconciliation (e.g. James 2010; Stanton 2011) and a definitional dispute over whether the residential schools were an attempted genocide (e.g. Grant 1996; Chrisjohn et al. 2006;MacDonald 2007; Woolford 2009). By bringing a social science framework to bear on an historical question, I hope to inspire similarly oriented research.

Another aim is to demonstrate the relevance of Jeffrey Alexander's 'strong program in cultural sociology' in the study of politics. Although Foucault's writings on governmentality have made significant inroads in political analysis, other cultural approaches have been less successful. By integrating aspects of Turner's social drama model into Alexander's approach it is hoped that it will make the latter more amenable to students of politics.

\section{A Cultural Approach to Politics}

In response to the persistence of the residential schools, Milloy seems to metaphorically throw his hands in the air in confused frustration, writing that their long history was due to 'thoughtless persistence' and suggesting that the school system had a 'life of its own' (Milloy 1999, p. 111). How might we explain the behaviour of the administrators involved in the residential schools and go some distance in resolving the puzzle that Milloy has brought to light? One way is to take a cultural approach. Such an approach can be useful in understanding social phenomena that seems to contradict ratiocinative logic because of its emphasis on the ways that behaviour is unconsciously structured by meanings and norms.

Since the cultural turn, there has emerged a variety of approaches. In this article, I will engage with a relatively recent arrival referred to as the 'strong program in cultural sociology' (for programmatic statements, see Alexander and Smith 2003; Alexander et al. 2012). The premise of this approach is that meaning is a relatively autonomous social force. It takes particular inspiration from Durkheim's Elementary Forms of the Religious Life (1995 [1912]), drawing on the concepts of 'sacred', 'profane' and 'mundane'. Here the sacred refers to taken-for-granted norms that exert behavioural claims upon the social life. It is that which we hold as 'good' (even if it can have negative consequences). It is not a synonym for religion or a religious understanding of God. The profane refers to phenomena that are perceived as potential pollutants of the sacred. The mundane refers to everyday phenomena and norms that are neither seen as sacred nor profane (Lynch 2012).

Alexander and his colleagues focus on how particular meanings of social phenomena (e.g. whether they are sacred, profane, or mundane) are established, contested and transformed. To help bring this process to light, they have recently turned to performance studies, drawing in large part on Victor Turner (Alexander 2004). Here Alexander argues that in modern complex social groups, behaviour that is intended to convey meaning can be analogised as 
theatrical performance.

In struggles over meaning, competing social actors are thus framed as involved in a performative struggle, with the wider group as the 'audience'. To successfully convey intended meanings to the wider group, social actors draw on shared aspects of culture (narratives, myths, symbols, practices) and make use of available communication technologies. Power is also acknowledged as a key factor in the success of a cultural performance. However, Alexander stresses that the outcome is not wholly dependent on power. For Alexander (2011), the fact that even dictatorships seek to perform legitimacy by drawing on shared meanings underscores the relative autonomy of such meanings.

The performative turn within the strong program makes the approach more attuned to agency and conflict, which makes it more relevant to the study of politics. In this regard, it provides a much needed update on the framing models developed by David Snow and Robert Benford (1988), which portray social actors' engagement with meaning as a nearly wholly instrumental endeavour. This ignores that even elites are often unaware of ways in which their actions are structured by, and draw upon, underlying meanings. By contrast, the strong program, with its grounding in classical sociology, acknowledges that social behaviour is often as 'expressive' as it is 'instrumental' (Alexander 1990, p. 11).

Despite the importance of Victor Turner's insights in the development of Alexander's approach, the phases associated with social drama model that Turner devised to analyse the cultural process by which political struggles erupt and attenuate have been dropped. Likely, Alexander did so to distance his approach from the taint of functionalism. However, there are compelling reasons for integrating Turner's model more explicitly with the strong program in certain instances. Specifically, Turner's model is a useful heuristic device for uncovering the meaning contending performances in relation to political processes. Combining the social drama model with the strong program can therefore help to make the latter more explicitly processual. Meanwhile, the insights of the strong program should help ensure that the social drama model is attuned to contingency.

Turner $(1974,1982)$ developed the social drama model to analyse the transitional phase of a social order, which is often marked by a symbolic politics in which competing actors seek to defend or consest meanings. Turner likened social dramas to a ritual process, in which meaning enters a 'liminal' (transitional, undefined) phase. Turner (1974) suggests that social dramas typically involve four stages: breach, mounting crisis, redress, and, finally, reintegration or schism. Crucially, the existence of these phases does not mean that one necessarily follows the other. As we saw in the discussion of Alexander's approach, struggles over meaning in complex societies can be highly contingent. From this perspective, the phases elucidated by Turner can be seen as a heuristic toolkit that can help clarify the meaning of political acts, not as an explanation of the cultural process of all political events in all instances.

The phases of the social drama are as follows. The breach refers to the transgression of some widely held norm. This transgression can trigger a phase of mounting crisis if a struggle ensues over how to interpret it. Whereas some groups may be interested in widening the breach, others will be interested in 'sealing' it. In this phase, the underlying meanings structuring the conflict will come into sharper relief. In the event that one group achieves the upper hand, its members will seek to resolve the crisis by moving it into a redressive phase. Redress occurs when leading members of the successful group use pragmatic and/or symbolic action to end the crisis. If this succeeds, the crisis will move into a phase of reintegration, during which antagonism subsides and meanings once again become relatively unconscious norms. If this does not occur, a permanent schism between the conflicting groups may result.

Before applying this combined Alexandrian cum Turnerian framework to the Anglican Church of Canada, a few words are in order regarding its application to a religious organization, given the strong program's association with Durkheim's Elementary Forms. Durkheim based his arguments on ethnographies of religious ceremonies of small, preindustrial Aboriginal groups in Australia. However, he suggested that his arguments were applicable to complex modern societies. The strong program gets its impetus from this proposition. Thus, while individuals in modern societies may see themselves as secularized rational actors, the strong program takes the view that their behaviour is nevertheless also structured by underlying meanings and norms. From this perspective, although belief in organized religion may have declined, individuals are still 'religious' actors - in the sense that they still demonstrate a concern for protecting sacred meanings. What are the implications of this proposition in the analysis of groups that do not claim to be secular?

In short, this does not pose a problem. One of the main claims of the strong program is that the binaries between sacred, profane and mundane can be found in all societies, irrespective of particular religious and ideological beliefs. We can therefore presume that the Anglicans I analyse will still make use of these basic elements of behaviour in their struggles over the meaning of the residential schools, irrespective of their particular belief systems. However, that being said, belief systems do influence how struggles over meaning proceed, and it is therefore necessary to also be attuned to this context. 


\section{A Sacred Enterprise}

In this section, I discuss why the Church of England in Canada agreed to take on the residential schools and the meanings that were subsequently attached to them. This provides the context for understanding the ways in which social actors engaged with the meaning of the residential schools during the struggle that I will analyse in subsequent sections.

Church leaders were initially 'delighted' with the government's proposal to fund a system of church-run Indian residential schools: these were funds being offered for work in which the church was already involved (Hayes 2004, p. 29). Since the outset of the nineteenth century, Britain-based Anglican missionary societies, such as the New England Company, the Society for the Propagation of the Gospel in Foreign Parts, the Society for the Propagation of Christian Knowledge and the Church Missionary Society (CMS), as well as non-denominational organisations, such as the Aborigines Protection Society, had taken interest in the welfare of Aboriginal peoples in North America and had supported education and missionary work among them as a way of 'elevating' them (i.e. assimilating them). The most influential of these was the CMS. The CMS became involved in Aboriginal education in Canada (formerly British North America) through the work of John West who set up a residential school in the Red River region (now the Province of Manitoba) in 1820 (Hayes 2004, pp. 18-22).

Why was the church, which was ostensibly primarily concerned with religious conversion, interested in cultural assimilation? The two aims were entwined in eighteenth century America. A view of Aboriginal people had emerged among Anglicans that they were so primitive as to be unable to comprehend Christianity without first acquiring some rudimentary knowledge of 'civilisation' (Strong 2007, p. 52). By the end of the nineteenth century, for many Anglican missionaries, the distinction between the evangelical and civilising impulse had become blurred (Usher 1971, pp. 2852). This blurredmission has come to be known as the 'civilising mission.' The view of Aboriginal people as something less than civilised was compounded by Anglicans' belief in the unique superiority of English culture (Axtell 1985, p. 25). Such a belief was fueled by the rapid expansion of the English/British Empire during the eighteenth century. Anglicans framed the civilising mission in the context of this expansion; imperial expansion was considered to be guided by divine providence and that God expected that the English would extend Christianity's reach in return (Strong 2007, p. 60).

The role that Anglicanism played in disseminating English culture and religion was put in the service of Empire following the American Revolution. Whereas before the revolution the colonial administration had been at pains to avoid being seen to privilege Anglicanism over other Protestant sects, after the revolution, Anglicanism was accorded a prominent position to help ensure that the remaining North American possessions stayed loyal (Strong 2007, p. 119). Lands were set aside for the church (known as the 'clergy reserves') and, for the first time in the Americas, an Anglican Bishop was appointed in 1787. Although it was not quite an established church, the privileges accorded to Anglicanism during this period are enough for some historians to see the church as having been 'partially' established (Westfall 1990, p. 96). This ensured that Anglican elites in the nineteenth century tended to be influential, conservative and deeply committed to ensuring that British North America remained British — they were Tory Loyalists par excellence. This characterisation endured long after the church lost its formal privileges in the 1850s (Hayes 2004, p. 68). Thus, when the Canadian government proposed the residential school system, church elites were all too willing to commit their church to it.

From the outset, the residential schools were represented as an extension and exemplar of a sacred (in the Durkheimian sense) narrative of the church's missionary work among Aboriginal peoples. The sacrality of this narrative had become entrenched among Anglicans over the course of the nineteenth century. In such a narrative, successful missionaries, such as John West, were represented as inspirational heroes who had braved harsh conditions to bring Christianity and civilisation to the 'heathen red man' and lay the foundations for the Canadian nation. The establishment of the sacred meaning of the church's missions in North America was, in large part, a result of cultural work performed by missionaries in the field, who published articles, reports, memoirs and books about their experiences. In general, these publications served to inspire new missionaries and sustained public interest in missionary work (Austin and Scott 2005, p. 5). At the time, stories about the missionaries working among North American Aboriginals were extremely popular (Hayes 2004, p. 19). The epitome of the genre in this period is Hiram A Cody's (2002) biography of Bishop Bompas, first published in 1908, which describes Bompas' missionary efforts among Aboriginals in the Arctic.

The sacred meaning of the missionaries was also performed via other textual forms. They are depicted, for example, in the stained glass frescoes that adorn many Canadian Anglican churches. The exploits of John West are particularly prominent in these. His success at teaching and evangelising in the North-West is visually narrated in the chapel at Wycliffe College in Toronto, which was for many years the principal Canadian training ground for Anglican missionaries bound for the North-West. West also appears in stained glass at St. John's College in Winnipeg, the site of the oldest Canadian Anglican parish west of the Great Lakes. 'Successful' missionaries' efforts were also inscribed in the Prayer Book Calendar; John West is recalled on 31st December. 
This section discusses the origins of the struggle over the meaning of the residential schools that occurred among Anglican elites in the first decade of the 20th century. At this time, the school system was expanding rapidly, leading to spiralling costs. The churches and the government entered into negotiations to find a way of sustainably funding the schools. The government proposed that the residential school system should be abandoned and replaced with day schools. Among the Anglicans, the dim financial situation was compounded by the CMS announcing in 1903 that it would withdraw from the Canadian field by 1920 (at the time, the CMS was the main supplier of funds and personnel). In view of all this, several churchmen, who were responsible for the newly created Toronto-based Mission Society of the Church of England in Canada (MSCC), welcomed the government's position and pushed for the church's withdrawal from the schools. A social drama was potentially in the making.

Before discussing the ramifications of the MSCC's position, some context on Canadian Anglicanism in this period is needed. For much of the nineteenth century, Canadian Anglicanism was highly decentralised; there was little in the way of national institutions and the weight of social power was held at the level of the Diocese. This began to change at the end of the century. In 1892, a General Synod was created with the administrative offices to be located in Toronto. Existing dioceses and provinces were incorporated into its structure. These changes impacted the church's missionary work. In 1902, the MSCC, which was to be the national body responsible for the Canadian church's missionary work, was created. One year later, the MSCC met with its first major challenge as a result of the announcement by the CMS and began to push for withdrawal from the residential schools. This sowed the seeds for conflict.

Historically, the dioceses in which residential schools were located had received support from the British mission societies directly. With the impending withdrawal of the CMS, there was an expectation that support would now flow from the newly formed MSCC. However, as mentioned above, the MSCC administration was not so beholden to the residential schools and instead sought to withdraw the church from its role in them. The struggle this produced had territorial dimensions. Because most of the residential schools were being built in the newly 'opened' northwestern regions of Canada (especially in the regions encompassing the provinces of Alberta and Saskatchewan), most of their support came from there. By contrast, the clergymen who were opposed to the schools were based in the central and eastern regions of Canada.

To return to the origins of the social drama, given the sacred meaning that had become attached to the residential schools, those that were opposed to them needed to transform their meaning if they were to succeed in withdrawing the church. Here, they were greatly helped by the 1907 publication of the Bryce Report (Bryce 1907). The report presents a harrowing picture of the conditions in the school system. It suggests that overcrowding, poorly trained personnel, inadequate infrastructure, insufficient nutrition, a lack of sanitation, had led to an abnormally high rate of disease and death in the school system. The report focused especially on the high death rate from tuberculosis in the schools, which was found to be $24 \%$, roughly double that of the wider population of Aboriginal people.

Notably, the Bryce Report was not necessarily a surprise to many administrators. Two other reports, published in the 1890s, had also commented on the poor state of the schools (Milloy 1999, p. 85). Yet, more than any other, the Bryce Report focused negative attention on the schools. This is likely due to Bryce distributing it widely among members of Parliament, the churches and the media (Milloy 1999, p. 90). The grim statistics captured the attention of the latter. An article published by the widely circulated Saturday Night wrote 'Indian boys and girls are dying like flies in these situations or shortly after leaving them ... even war seldom shows as large a percentage of fatalities as does the education system we have imposed on our Indian wards ... [it was] ... a situation disgraceful to the country' (Milloy 1999, p. 91).

The publication of the Bryce report destabilised the meaning of the residential schools. In Turner's terms, its meaning had become less fixed and more liminal. This provided a catalyst for the several church members to ramp up their opposition to the school system. As such, the Bryce Report can be seen as instigating the 'breach' that can precede a social drama.

\section{Crisis}

Several members of the Board of Management of the MSCC sought to exploit the potential liminality in the meaning of the residential schools triggered by the Bryce Report in order to withdraw the church from them altogether. Leadership was provided by Samuel Hume Blake, a Toronto lawyer who was a member of the Board of Management of the MSCC, Chair of the organisation's Special Indian Committee, and generally influential figure in the church (Hayes 2004, pp. 32-33).

In a series of pamphlets and letters, Blake seeks to convince other church leaders to support the government's proposal to replace the residential schools with a system of 'improved day schools.' To do so, much as Blake focuses 
on ratiocinative reasons for withdrawing from the residential schools, he also focuses on meaning. Indeed, Blake's primary concern (and that of his opponents, as we shall see shortly), seems to have been primarily focused on the meaning of the residential schools, rather than on any 'objective' facts that the Bryce Report may have brought to light. As such, I interpret his emotionally charged pamphlets and letters as cultural performances intended to detach the residential schools from their sacred meaning.

Before addressing Blake's efforts, it should be explained why he and his colleagues were so willing to give up the residential schools. After all, if the school system had previously been represented as sacred should they not have been concerned with protecting it? The reason why they were not seems to be due to them being based in Toronto, which was growing rapidly from immigration and in which Aboriginal peoples were a rapidly decreasing minority. In this context, a view arose that the church was focusing too much of its resources on Aboriginal people, whose population was then seen by many to be in terminal decline, when resources might more fruitfully be oriented to the many settlers who were then arriving in the country (Porter 1981, p. 56).

Blake's performative strategy is focused on detaching the residential schools from the long-established sacred narrative of church's mission to evangelise to non-Christians. To do so, he frequently represents the school system as a normal secular (i.e. mundane) educational institution against what he considers to be church's 'true' (i.e. sacred) mission to evangelise. In one pamphlet, Blake demands rhetorically:

'To what extent is the work carried on to-day by our Church, Missionary work of the class contemplated by this society? Is the general work of education in the Schools as found to-day such work [...]? (Blake 1908a, p. 6)

Similarly, Blake (1907, p. 40) declares elsewhere: 'This work [in the residential schools] has ceased to be missionary, [and] must not be allowed to prevent the onward movement intended.'

In his effort to attach a mundane meaning to the residential schools, Blake also invokes the narrative of the 'heroic' adventurer-missionary that was frequently represented in the popular missionary literature of the era, who ostensibly roamed the land with the 'heathen red man', bible in hand. The implication is that the residential schools were of an entirely different order and not really missionary work. In this regard, Blake (1907, p. 7) demands: 'should this Society [the MSCC] confine its aid to the aggressive work as largely carried on in earlier days by travelling missionaries whose life was spent among the bands of Indians as they wandered through their hunting grounds or assembled in their encampments when hunting was over?'.

Blake also frequently reminds his readers of other 'true' missionary fields that also require the church's attention, including the many thousands of settlers then arriving Canada. Blake (1908a, p. 8) writes: 'if the Church were freed from the everyday details and expense of the schools, a large field, at present untouched, might be covered'.

Blake also seeks to convey that day schools were a better mechanism by which to civilize Aboriginal people. Here, Blake makes use of the symbol of the family, which, he suggests, the day schools would protect.

'this [the 'new and improved' day school] in place of separating, draws together the parent and the children, and continues and increases the interest of the one in the other, and sends out, by means of the children, the education of the teacher far beyond the limits of the school-house and makes it the pulse to be felt all through the reserve. This to my mind, would be a blessed system ...' (Blake 1908b, p. 7)

It is possible that Blake's efforts to represent the residential schools as mundane institutions might have succeeded, and the Anglican Church's role in their tragic consequences might have ceased early in the twentieth century. Unfortunately, Blake was resisted by his western brethren, who were able to make use of their greater access to social power to successfully counter his efforts.

\section{Redress}

This section discusses the efforts of several prominent western-based Anglicans to defend the sacred meaning of the residential schools. In the context of the social drama, these efforts can be seen as an attempt to repair the breach that Blake sought to pry open. Among the western church elites, in whose dioceses the majority of residential schools were based, the outset of the twentieth century was a period of optimism regarding the residential school system, which had been expanding rapidly. Unlike in urban central Canada, where rapid social change was rendering such a meaning redundant, among the western churchmen, the residential schools remained firmly attached to their sacred meaning. They were therefore dismayed by the MSCC's response to the Bryce Report.

In partnership with representatives of the other protestant churches involved in Aboriginal education, the western churchmen created a pressure group known as the western committee. The committee 'rejected all the charges that 
had been levelled against the residential schools and announced that it was not prepared to consent to any reduction in their numbers' (Porter 1981, p. 65). The committee was headed by Anglican Bishop Pinkham. Pinkham was directly affected by the controversy: his diocese contained two schools that had been singled out by Bryce for their lack of proper sanitation, and, as a consequence, had been designated for immediate closure by the government. As a preventative measure, Pinkham withdrew the schools in his diocese from the MSCC's management.

In same year, an Anglican delegation under the leadership of Archdeacon John Tims, Superintendent of Indian Missions in the Diocese of Calgary, participated in a 'convention of the Friends of the Indian and Half-Breed Population of Alberta in Edmonton' to drum up support for their resistance to the closure of the residential schools (Porter 1981, p. 65). Following the convention, Tims published a widely-circulated pamphlet (Tims 1908). During this time, his fellow churchmen also sent numerous letters to the Anglican weekly, the Canadian Churchman, the MSCC, and various officials in the Department of Indian Affairs.

Notably, although the Bryce Report played a central role in triggering the struggle over the residential schools, it is not once mentioned in any of the aforementioned letters and pamphlets published by the western churchmen. Rather than dispute the verity of the claims made in the report, they engage in a struggle over meaning, emphasising the symbolic links between the residential schools and the church's historicmissions among Aboriginal people in North America. The intent of such a strategy is to ensure that the residential schools remain framed as 'true' (i.e. sacred) missionary work. For example, Tims writes: 'The fact is the School System nowhere takes the place of evangelistic effort, but is supplementary to it. Schools do not compete with the missionary, they carry on his work' (Tims 1908, p. 3).

Even when they do admit that there are problems in the residential schools, the western churchmen portray such problems as a source of inspiration to redouble efforts in the residential schools rather than withdraw. Thus, Arthur Barner (1909), a residential school principal, argues: 'The change needed in this province is not a change of system but rather the strengthening of the Residential School system so that unsanitary conditions may be removed, old buildings replaced with new, up to date structures, better equipment for carrying on the work and a compulsory law to deal with stubborn cases'.

In making an appeal for an improved residential school system, the western churchmen make their most powerful symbolic move, which is to draw on the narrative of the church's ostensible providential duty to civilise Aboriginal people. Armed with this narrative, Tims represents Blake's recommendations as a betrayal of the church's heroic predecessors and of God. Tims (1908, p. 5) writes: '... we wish to express and emphasise our opinion that to deny even a few hundred Indians 'the Bread of Life' ... will be to be false to ourselves, our country and our Church, and to be unworthy followers of the noble men who gave their lives as pioneers to the Indian work'. Tims goes on to recommend that the church launch an appeal to pay for the improvement of the residential schools: ' $\ldots$ appeal with boldness and confidence to every individual and section of the Church — white and Indian, high and low, rich and poor, east and west' (Tims 1908, p. 6).

By the end of 1908, the pendulum had swung towards the western churchmen. Just a few months after the government presented its proposal to replace the residential schools with day schools, it reversed its position. Faced with pressure from the western churchmen, Frank Pedley, Deputy Superintendent General of the Department of Indian Affairs, noted 'there is not absolute unanimity amongst the Protestants as there is considerable opposition from influential quarters, notably from the Bishop of Calgary' (cited in Porter 1980, pp. 68-9). In 1909, the Department presented the churches with a new plan that was in line with the demands of the western churchmen and, surprisingly, even included provisions for expansion of the school system.

The reason for the western churchmen's success is due to their political influence (Porter 1980, p. 79). Here is where meaning interacts with social power. As Alexander stresses, no matter how skilful social actors 'cultural performers' are asymmetries in social power will be an important factor in determining their success. At this juncture, Canadian Anglicanism had only recently created a centralised structure and the balance of social power remained in the hands of the dioceses. Thus, when the government invited the churches to Ottawa to discuss its new proposal, it only invited members of the western committee, completely bypassing the newly-formed MSCC (Porter 1980, p. 74). Moreover, the new contract that was eventually agreed upon designated that it was to be signed by 'the bishops in whose dioceses the schools were located' (Porter 1980, p. 74).

Following their triumph with the government, the western churchmen ramped up their struggle against the MSCC. In October 1910, a delegation went to Toronto to present their case. In view of the government's reversal, the MSCC accepted the western position. A resolution was passed setting aside funds for the residential schools (Porter 1980, p. 76). With this, the MSCC acknowledged that the residential schools were indeed sacred and that they were therefore 'true' missionary work. This was reinforced in 1918 when the General Synod adopted a report asserting that the residential schools were 'essential' elements of the church's missionary work (Porter 1980, p. 80). With the MSCC taking responsibility for the residential schools, the struggle attenuated and the western dioceses began to participate 
more fully in the national church. In 1920, the Indian Committee of the MSCC drew up a document recognising the MSCC as 'the sole body capable of representing the church in any negotiations with the government in matters concerning Indian education' (Porter 1980, p. 80).

From the perspective of the social drama, the western churchmen successfully re-sealed the breach in the sacred meaning of the residential schools, which Blake and his colleagues had tried to exploit. Despite indications that the conditions at the residential schools were deplorable and despite an impending funding shortfall, Blake had failed to convince the church that the schools were but a 'mundane' enterprise that had unfortunately failed and that it was now time to withdraw as a result. Instead, the crisis ended with the sacred meaning of the residential schools re-asserted.

\section{Reintegration}

This section discusses the conclusion of the social drama, wherein it is suggested that Canadian Anglicanism entered a phase of reintegration. In such a phase, underlying meanings unearthed during the social drama are re-submerged to become, once again, relatively unconscious normative frameworks structuring behaviour.

Although the sacred meaning of the residential schools had been successfully defended, the question remained as to the church would pay for them in light of the impending withdrawal of the CMS. In 1918, the church took up the idea that had originally been advanced by Tims and embarked on a nation-wide appeal for funds, entitled the 'Anglican Forward Movement', which was to coincide with the end of the FirstWorldWar and would also involve the raising of funds for general church expenses. The appeal involved a massive effort. Over 2,500,000 pamphlets were mailed to parishes throughout Canada, which were distributed by over 2,000 Women's Committees. Several hundred laymen were sent to every parish in the country to give presentations on the appeal. Special prayers relating to the appeal were also sent to clergymen throughout the country, with the directive that they be read during services. These efforts were extremely successful; by 1921, nearly \$500,000 (CAD) had been raised (Anglican Forward Movement 1919). From the perspective of the social drama that had preceded it, one effect of the appeal was to re-establish the sacred meaning of the civilising mission and the centrality of the residential schools in the conscience collective of the church membership.

To inspire donations, the literature associated with the appeal frequently draws upon the sacred narrative about the church's 'heroic' predecessors. To refuse the appeal was represented as a betrayal of their work. By contrast, to support the appeal was to participate in carrying out the church's sacred historic mission. Thus, one pamphlet states:

'The first reason why we cannot forego, but must assume, the complete responsibility is historical in its character. No organized body, least of all any branch of the Church Universal, can ignore the plain teachings of its history and expect to grow and prosper. The roots of the Church of England in Canada go down deeply into the soil of missionary work on behalf of the Indians and Eskimo' (Anglican Forward Movement 1919).

After providing examples of this 'heroic' work, the pamphlet ends on an inspiring note:

'The Church of England in Canada possesses, in the story of the missions to the Indians and Eskimo, a history rich in heroism and unsurpassed in the pricelesstreasures of courage and example. We dare not, we cannot, do anything to-day which would in any degree, whatsoever, prove ourselves unworthy of those who have gone before, or of the inheritance they have passed to us' (Anglican Forward Movement 1919).

By the time the appeal was complete, the fact that there had been significant opposition to the residential schools within the church was erased from the official church narrative. The church was now represented as heroically responding in unison to the withdrawal of the CMS. For example, one report states:

'The CMS would finally withdraw and leave the responsibility [for the residential schools] upon the Church in Canada. The Church could not repudiate that responsibility, without indelible disgrace and therefore the Board of Management, in 1918 took practical steps to meet the situation ...' (Anglican Forward Movement, 1921).

Unfortunately, despite a successful appeal, it seems that very little was done in the way of actually improving the residential schools. Instead, conditions worsened (Milloy 1999, pp. 95-107). In 1922, Bryce grew so exasperated with the seeming inability by church and state to rein in the spread of disease in the schools that he republished his report. Yet, despite their increasingly dire reality, the residential schools retained their sacred meaning. In 1939, the Secretary of the Anglican Indian and Residential School Commission produced a pamphlet aimed at inspiring donations that described the residential schools as a 'blessing' (Westgate 1938). By that time, the school system had become the biggest single item in the MSCC's budget (Hayes 2004, p. 31).

Concluding Remarks 
With the aim of shedding light on why the residential schools persisted for so long despite their high costs and deplorable record, I sought to bring to light the role that meaning played in this. To do so, I focused on a struggle over the meaning of the residential schools among Canadian Anglican elites that occurred in the early part of the twentieth century, which I reframed as a social drama. By focusing on a period of struggle, which, as Turner suggests (1974, p. 35), 'seems to bring fundamental aspects of society, normally overlaid by the customs and habits of daily intercourse, into frightening prominence', I was able to better uncover the meanings that had become attached to the residential schools.

The most significant finding was that the meaning of the residential schools as an extension of the church's sacred civilising mission was extremely important in structuring the terms of the social drama. Thus, in the effort to withdraw the church from the residential schools, Blake sought to detach them from such a meaning by suggesting that they were merely mundane educational institutions that had little to do with 'true' mission work. Against this, Blake's opponents devoted their efforts to affectively 'proving' that the residential schools were indeed 'true' mission work. They did so by pointing to their ostensibly heroic predecessors, such as John West. That the sacred encoding of the residential schools played an important role in structuring behaviour can also be seen in the way that the social drama was resolved. After the defenders of the residential schools had won out over Blake and his cohort, they still needed to find the funds to operate them. Here they drew on the sacred meaning to inspire donations from the wider church membership.

Thus, the foregoing analysis suggests that one reason why the Anglican Church persisted in supporting the residential schools as long as it did was because they had become attached to a sacred meaning. If the residential schools system had merely been represented as a mundane educational institution like any other, given the high costs associated with them and their poor health conditions, the church might have supported their replacement with day schools. Problematically, this was not the case, and because the group with the most social power was the most invested in defending the residential schools, they retained their sacred meaning. As a result, the church remained embroiled in perpetrating an immense tragedy for many more years.

A potential criticism of my argument is that I ignored instrumental factors in the decision by the western churchmen to defend the residential schools. For example, many of the defenders of the residential schools, such as the school staff members, were also defending their jobs. Among the Bishops who defended the residential schools, whose jobs were not necessarily at stake, they also stood to suffer a loss of prestige along with a much diminished operating budget and smaller staff. These are important points and I should be clear that by focusing on meaning, I do not mean to deny instrumental factors in structuring the defence of the residential schools. However, I do not think that greater emphasis on such factors would negate my findings.

Even if the defenders of the residential schools were instrumentally driven, this does not detract from the fact that they needed to engage with meaning in order to enact an effective (and affective) defence. And the very fact that, in doing so, they were concerned with defending the sacred meaning of the residential schools suggests that such a meaning was important in ensuring that the school system persisted. It is the fact that the various social actors involved in the drama needed to engage with a particular meaning that reveals the relative autonomy of this meaning as a social force. As we saw in this article, they did not haphazardly make use of a mix of meanings when referring to the residential schools. Both the opponents and proponents of the residential schools engaged with a specific meaning that had a priori been established.

Limited by its focus on only one of the former partners in the residential schools, this article begs for further research on the other social actors formerly involved in the residential schools. It would be especially interesting to apply the approach developed here to the Roman Catholic Church in Canada. Canadian Anglicanism in this period was a bastion of elite English Canada and, as such, the church's collective identity was represented as being indelibly tied up with (English) Canada's national identity. Participation in the residential schools was thus, in part, narrated as a duty to the British Empire and, subsequently, to the Canadian nation. By contrast, the Roman Catholic Church's membership has historically been drawn from French Canada, which has often been at odds with the Canadian nationstate. How did this impact upon the way in which the residential schools were represented within the Catholic Church?

There is also scope for a cultural approach to shed light on other significant periods in the history of the residential schools from the perspective of the churches. For example, one period that has not yet been adequately addressed is that which followed the government's decision to terminate the church's role in the residential schools in the 1960s. After this, the churches rejected the sacred meaning of the civilising mission (and the role of the residential schools in this) and embarked upon a new ostensibly sacred mission, in which they would begin to work on behalf of Aboriginal peoples. The process by which such change occurred has not yet been adequately addressed.

It is hoped this article has helped demonstrate the relevance of Alexander's strong program in the study of politics. By 
integrating elements of Turner's model into Alexander's approach, I sought to develop a framework that acknowledges contingency but is also attentive to the processual nature of politics. And although this framework was used in analysis of a struggle that was admittedly fairly civil, I am convinced that it is robust enough to be used in other, more contentious, types of struggle.

\section{References}

Aboriginal Affairs and Northern Development Canada, Indian Residential Schools, Frequently Asked Questions. Available from http://www.aadncaandc.gc.ca/eng/1348071781555/1348071862685. Accessed 10 Oct 2012.

Alexander, J. C. (1990). 'Introduction: Durkheimian Sociology and Cultural Studies Today'. In J. C. Alexander (Ed.), Durkheimian Sociology: Cultural Studies. Cambridge, UK: Cambridge University Press.

Alexander, J. C. (2004) Cultural Pragmatics: Social Performance between Ritual and Strategy. Sociological Theory 22(4):527-73.

Alexander, J. C. (2011). Performance and Power. London: Polity.

Alexander, J. C., \& Smith, P. (2003). The Strong Program in Cultural Sociology: Elements of a Structural Hermeneutics. In J. C. Alexander (Ed.), The Meanings of Social Life: A Cultural Sociology. Oxford: Oxford University Press.

Alexander, J. C., Smith, P., \& Jacobs, R. (2012). 'Introduction: Cultural Sociology Today'. In J. C. Alexander, P. Smith \& R. Jacobs (Eds.), Oxford Handbook of Cultural Sociology. Oxford: Oxford University Press.

Anglican Church of Canada. Historical Sketch for Anglican Residential Schools. Available from http:// www.anglican.ca/relationships/trc/schools. Accessed 9 Oct 2012.

Anglican Forward Movement (1921). Report of the Executive Committee. Reports, GS 75-38, Box 1. Toronto: Anglican Church of Canada General Synod Archives.

Anglican Forward Movement. (ca. 1919). A Debt We Owe. Educational Pamphlet Series, No 8, GS 75-38. Toronto: Anglican Church of Canada General Synod Archives.

Austin, A., \& Scott, J. S. (Eds.). (2005). Canadian missionaries, indigenous peoples: representing religion at home and abroad. Toronto: University of Toronto Press.

Axtell, J. (1985). The invasion within: the contest of cultures in Colonial North America. Oxford: Oxford University Press.

Blake, S. H. (1907). To the Members of the board of management of the missionary society of the Church of England in Canada. Blake, Samuel Hume, 1835-1914, MM52 B467.4, GS 75-103, Box 3, File 1.

Toronto: Anglican Church of Canada General Synod Archives.

Blake, S. H. (1908a). The church's missions amongst aborigines in America. Blake, Samuel Hume, 18351914, MM52 B467, GS 74-103, Box 3, File 1. Toronto: Anglican Church of Canada General Synod Archives.

Blake, S. H. (1908b). Letter to His Grace the Archbishop of Rupert's Land Regarding Indian Schools. Blake, Samuel Hume, 1835-1914, MM52 B467.1, GS 74-103, Box 3, File 1. Toronto: Anglican Church of Canada General Synod Archives.

Barner, A. (1909). Memorandum on Indian Work. Blake, Samuel Hume, 1835-1914, MM52 B467, GS 74103, Box 3, File 1. Toronto: Anglican Church of Canada General Synod Archives.

Bryce, P. H. (1907). Report on the Indian schools of Manitoba and the North-West territories. Toronto: Anglican Church of Canada General Synod Archives.

Canada (1996). Report of the Royal Commission on Aboriginal Peoples. Ottawa: The Commission.

Chrisjohn, R. D., Young, S. H., \& Maraun, M. (2006). The circle game: shadows and substance in the Indian residential school experience in Canada. Penticton, BC: Theytus Books.

Cody, H. A. (2002). An apostle of the North: memoirs of the Right Reverend William Carpenter Bompas. Edmonton, Alta: University of Alberta Press.

Grant, A. (1996). No End of Grief: Residential Schools in Canada. Winnipeg, Ma: Pemmican Publications Inc.

Hayes, A. (2004). Anglicans in Canada: Controversies and Identity in Historical Perspective. Chicago, Ill: University of Illinois Press.

James, M. (2010). Uncomfortable comparisons: the Canadian truth and reconciliation commission in international context. Les ateliers de l'éthique, 5, 23-35. 
Larmondin, L. (2001). Native Bishop Forgives Church and Primate. Anglican Communion News Service 12 July.

Lewis, M. R. (1966). The Anglican Church and its mission schools dispute. Alberta Historical Review, 14, 7-13.

Lynch, G. (2012). The sacred in the modern world. Oxford: Oxford University Press

MacDonald, D. (2007). First nations, residential schools, and the Americanization of the Holocaust: rewriting indigenous history in the United States and Canada. Canadian Journal of Political Science, 40, 9951015.

Miller, J. R. (1996). Shingwauk's vision: a history of native residential schools. Toronto: University of Toronto Press.

Milloy, J. S. (1999). 'A national crime': the Canadian government and the residential school system, 18791986. Winnipeg, MA: The University of Manitoba Press.

Porter, E. (1981). The Anglican Church and Native Education: Residential Schools and Assimilation. PhD dissertation, University of Toronto.

Smith, D. G. (2001). The "policy of aggressive civilization" and projects of governance in Roman Catholic Industrial Schools for Native Peoples in Canada, 1870-95. Anthropoligica, 43, 253-271.

Snow, D. A., \& Benford, R. D. (1988). Ideology, frame resonance, and participant mobilization. International Social Movement Research, 1, 197-218.

Stanton, K. (2011). Canada's truth and reconciliation commission: settling the past? The International Indigenous Policy Journal, 2, 1-18.

Strong, R. (2007). Anglicanism and the British Empire, 1700-1850. Oxford: Oxford University Press.

Tims, J. W. (1908). The call of the red man for truth, honesty and fair play. MM 29.7T38, GS 75-103, Box 3, File 1. Toronto: Anglican Church of Canada General Synod Archives.

Truth and Reconciliation Commission of Canada. 'About Us'. Available from, http://www.trc.ca/websites trcinstitution/index.php?p=3. Accessed 1 Feb 2013.

Turner, V. (1974). Dramas, fields and metaphors: symbolic action in human society. Ithaca, NY: Cornell University Press.

Turner, V. (1982). From ritual to theatre: the human seriousness of play. New York: Performing Arts Journal Publication.

Usher, J. (1971). Apostles and aborigines: the social theory of the Church Missionary Society. Histoire Sociale-Social History, 7, 28-52.

Westfall, W. (1990). Two Worlds: The Protestant Culture of Nineteenth-Century. Ontario, Montreal and Kingston: McGill-Queen's University Press.

Westgate, T. B. R. (1938). The Indian and Eskimo residential schools: this material was provided by Rev. T.B.RWestgate, D.D. M.S.C.C. 9-5, Popular Information Series, GS 75-103, Box 130. Toronto: Anglican Church of Canada. General Synod Archives.

Woolford, A. (2009). Ontological destruction: genocide and Canadian aboriginal peoples. Genocide Studies and Prevention, 4, 81-97. A Cultural Approach to a Canadian Tragedy. 